\title{
Human Genome Evolution and Development of Cardiovascular Risk Factors Through Natural Selection
}

\author{
R. POLEDNE ${ }^{1}$, J. ZICHA ${ }^{2}$ \\ ${ }^{1}$ Institute of Clinical and Experimental Medicine, Prague, Czech Republic, ${ }^{2}$ Institute of Physiology \\ of the Czech Academy of Sciences, Prague, Czech Republic
}

Received February 7, 2018

Accepted February 12, 2018

\section{Summary}

Impressive advances in molecular genetic techniques allow to analyze the effects of natural selection on the development of human genome. For example, the trend towards blonde hair and blue eyes was documented. The approach to analyze possible effects of natural selection on the evolution of recent phenotypes with high risk of cardiovascular disease has not been described yet. A possible effect on the evolution of two main risk factors hypercholesterolemia and hypertension - is presented. The close relationship of non-HDL cholesterol blood concentration to the proportion of pro-inflammatory macrophages in human visceral adipose tissue might be a result of long-lasting natural selection. Individuals with higher proportion of this phenotype might also display a higher ability to fight infection, which was very common in human setting from prehistory until Middle Ages. Successful battle against infections increased the probability to survive till reproductive age. Similar hypothesis was proposed to explain frequent hypertension in African Americans. A long-lasting selection for higher ability to conserve sodium during long-term adaptation to low sodium intake and hot weather was followed by a short-term (but very hard) natural selection of individuals during transatlantic slave transport. Only those with very high capability to retain sodium were able to survive. Natural selection of phenotypes with high plasma cholesterol concentration and/or high blood pressure is recently potentiated by high-fat high-sodium diet and overnutrition. This hypothesis is also supported by the advantage of familial hypercholesterolemia in the 19th century (at the time of high infection disease mortality) in contrast to the disadvantage of familial hypercholesterolemia during the actual period of high cardiovascular disease mortality.

\section{Key words}

Natural selection • Macrophages/monocytes • Inflammation • Atherosclerosis • Non-HDL cholesterol • Membrane receptors • Renal sodium handling • Sodium conservation • Hypertension • Cardiovascular risk factors • Urbanization • Migration • Adaptive and maladaptive traits

\section{Corresponding author}

R. Poledne, Institute for Clinical and Experimental Medicine (IKEM), Vídeňská 1958/9, 14021 Prague 4, Czech Republic. E-mail: rupo@ikem.cz

The evolution by natural selection is considered to be a supreme organizing principle of biology, but it has not been widely applied in medicine (Nesse et al. 2006). Evolutionary medicine has been hardly neglected in most cardiovascular research (Weder 2007). Thanks to impressive advances in techniques of molecular genetics, the last few millennia witnessed a polygenic shift in men. These techniques have been focused on identifying signs of strong selection at different loci of human genome (Vitti et al. 2013).

Testing for differences in allele frequencies between ancient DNA and model samples is potentially effective, bringing the evidence of positive selection of skin, hair and eye pigmentation over the last 5,000 years (Wilde et al. 2014). Despite problems related to an adequate number of well-preserved ancestor DNA samples and the definition of a closely related current population, the above techniques revealed a trend towards blonde hair and blue eyes. This technique suggests that polygenic selection plays a role in many complex traits. 
This selection is an important force in modifying genetic variations resulting in a substantial variation of phenotypes in different pathologies within historical times.

Another example of a polygenic shift was well analyzed in various populations. It is the most frequently studied difference of long-term lactose effects on the selection of the proportion of lactase persistence and non-persistence in various populations. Lactase (lactase phlorizin hydrolase, EC3.2.1.62) is an enzyme-cleaving disaccharide lactose into glucose and galactose during the process of absorption of milk and dairy products. Unlike lactose, these monosaccharides are easily absorbed. Insufficient lactase enzymatic activity in the small intestine results in lactose intolerance, which occurs in childhood and presents with bloating and diarrhea (Flatz and Rotthauwe 1977). The only variation of the lactase gene is variant rs4988235 at position $13910 \mathrm{C} / \mathrm{T}$ (Olds and Sibley 2003) located within the neighboring MCM6 gene. C-T exchange at position 13910 is associated with lactase persistence (Mattar et al. 2012). Lactase persistence due to the T-allele is found in about $70 \%$ of European population (Tag et al. 2008), whereas it is only in about $10 \%$ of Indian population (Mendizabal et al. 2011). It is a very good example of a positive selection of lactase persistence in populations with high intake of milk and dairy products, as non-persistent individuals may not survive to the reproductive period of life.

Here we describe two examples of natural selection and monitoring genome changes. One of these selection processes lasted more than 50,000 years, whereas the other only a few centuries, but both processes are manifested due to recent negative environmental effects of overnutrition and high consumption of saturated fats. As both examples, hypercholesterolemia and hypertension, represent the most important cardiovascular risk factors, we believe that such selection and genome changes play a substantial role in the recent state of human health.

Inspired by a review of Aguilar and Fernandez (2014), which summarized recent data on the cholesterol/macrophage relationship in experimental models, we thought to analyze the relationship between pro-inflammatory macrophage status of adipose tissue and cholesterolemia in men. The analysis of this type of pro-inflammatory status by determining macrophage phenotypes in adipose tissue is rather complicated, because surface markers for normally and alternatively polarized macrophages have not yet been clearly identified. The prevalent opinion is that the presence of the CD16 receptor together with CD14 is sufficient for the identification of pro-inflammatory, normally polarized macrophages called as M1 (Aguilar-Ruiz et al. 2011). On the other hand, circulating monocytes without CD16 (CD16 ) are thought to belong to alternatively stimulated macrophages (Rogacev et al. 2014, Sheedy et al. 2013). In our studies, which analyzed proportion of pro-inflammatory and anti-inflammatory macrophages we found that high expression of surface marker CD36 helps to identify pro-inflammatory macrophages more precisely $\left(\mathrm{CD} 14^{+}, \mathrm{CD} 16^{+}, \mathrm{CD} 36^{+++}\right)$. On the contrary, the presence of the marker CD36 in alternatively stimulated macrophages was very low. We were able to document that an increasing proportion of $\mathrm{CD}^{+} 4^{+}$, $\mathrm{CD}_{16}{ }^{+}, \mathrm{CD} 36^{+++}$macrophages is positively related to BMI, age (sexually different) and non-HDL cholesterol (Kralova Lesna et al. 2015, Kralova Lesna et al. 2016, Poledne et al. 2016). All these data were obtained by analysis of visceral adipose tissue obtained peroperatively from the living kidney donors.

Our data on the strong relationship of intravasal cholesterol concentration to inflammation principally confirm the bi-directional effect of cholesterol molecules and pro-inflammatory macrophages, as suggested by different experimental models as well as by tissue culture studies (Medbury et al. 2015, Yvan-Charvet et al. 2008, Tall and Yvan-Charvet 2015). Independently of the mechanism, the close relationship of non-HDL cholesterol to pro-inflammation status of human visceral adipose tissue is in line with the recently summarized data on cholesterol and inflammation in experimental models fed a high-fat, high-cholesterol diet (Tall and Yvan-Charvet 2015). This type of diet in experimental models does not correspond to the situation in men as mice and rat display very low cholesterol concentration (with exception of genetically modified animals Bobková et al. 2004, Kovář et al. 2009).

There is no explanation for this surprising species difference. It might be ascribed by high-fat diet in industrially developed societies and then this recent situation might be compared with experimental models. An alternative explanation for the relationship between non-HDL cholesterol and pro-inflammatory macrophages in adipose tissue might be based on the evolution of the human genome over the past 50,000 years. It is of interest that the concentration of total cholesterol and its distribution among lipoprotein fractions in men is substantially different from other mammals. The total 
cholesterol concentration in healthy individuals is twice as high as in rodents (Table 1). Even more different is the distribution of cholesterol among particular lipoprotein fractions. In the rat the main part of plasma cholesterol is found in the high density lipoprotein fraction, playing a protective effect in the development of atherosclerosis (partly because of its participation in reverse cholesterol transport). In contrast, the concentrations of low and very-low density fractions largely involved in transporting cholesterol molecules from the liver to all extrahepatic cells are dominant in men (Kovár and Poledne 2004, Kovář et al. 2009).

Table 1. Plasma lipids in men and rodents - ultracentrifuge separation of lipoprotein fractions in 18 samples of human sera while in rats and mice pooled samples of sera were separated in triplicates.

\begin{tabular}{lccc}
\hline Species & Homo sapiens & Rattus norvegicus Wistar & Mus musculus C57BI/6 \\
\hline Cholesterol & $4.79 \pm 0.95(18)$ & $1.68 \pm 0.19(8)$ & $2.39 \pm 0.12(8)$ \\
$T G$ & $1.29 \pm 0.52$ & $1.22 \pm 0.18$ & 0.20 \\
$V L D L-C$ & $0.29 \pm 0.17$ & 0.22 & 0.11 \\
$I D L-C$ & $0.08 \pm 0.04$ & 0.04 & 0.33 \\
$L D L-C$ & $2.95 \pm 0.89$ & 0.14 & 1.93 \\
$H D L-C$ & $1.26 \pm 0.23$ & 1.42 & \\
\hline
\end{tabular}

\section{CD14+CD16+CD36+++ \%}

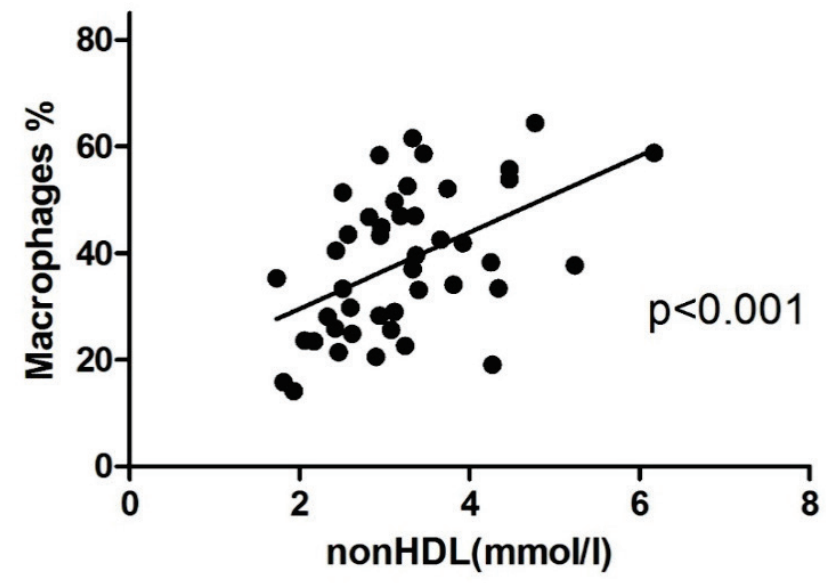

Fig. 1. Relationship of pro-inflammatory macrophages proportion to the concentration of non-HDL cholesterol in the visceral adipose tissue of living kidney donors $(n=52)$ (modified from Poledne et al. 2016).

Although there are some differences between populations in terms of the consumption of diets with a high proportion of saturated fatty acids, individual differences in LDL cholesterol depend on the geneenvironmental interaction. However, LDL cholesterol concentration in vegans is still much higher compared to other mammals. With the exception of monogenic familiar hypercholesterolemia, an overwhelming majority of individuals with higher cholesterol concentrations have polygenic hypercholesterolemia with the involvement of numerous candidate genes. The present higher concentrations of plasma cholesterol in men are the result of long-term selection process and consequent human genome development, whereby a higher LDL cholesterol concentration was definitely an evolutionary advantage.

We have recently found a very close relationship between non-HDL cholesterol concentration and the proportion of pro-inflammatory phagocytic, and normal stimulated macrophages in visceral human adipose tissue. This relationship was demonstrated in the analysis of these phagocytic monocytes defined by surface markers present CD14 and CD16 and high expression of CD36 in the adipose tissue of healthy individuals. Their adipose tissue was obtained during cleansing of the kidney of living kidney donors for kidney transplantation (Fig. 1). It is of interest that this close relationship is present not only in the individuals with higher cholesterol concentrations but also in subjects with strictly normal cholesterol concentration up to $4 \mathrm{mmol} / \mathrm{l}$. One could conceivably hypothesize that a high cholesterol concentration was associated with a high proportion of phagocytic macrophages in adipose tissue. If that is the case, then the individuals with higher phagocytic activity 
of macrophages are better prepared to cope with an infectious attack. When the man during his evolution began to use at least partly domesticated animals, he moved with them to covered dwellings and his conditions of living changed substantially. The price for a better protection against cold and moisture was a higher probability to develop infections in settings with permanent presence of human and animal feces.

Under these circumstances, any infection had a greater impact on the life span. An individual with a more pronounced defense - a higher proportion of phagocytic macrophages - was at a relative advantage. However, a higher proportion of defending phagocytic macrophages was accompanied with an increase of cholesterol concentrations. This relative advantage persisted much longer and was also present in the Middle Ages when all wastes were thrown in the streets and infectious diseases were the main problem of societies. Here again, this relative advantage of individuals with a higher proportion of phagocytic macrophages in their adipose tissue combined with a higher cholesterol concentration lasted until the 20 th century. The individual with the advantage of a higher resistance to infection is more likely to have a longer life span and also a higher probability of reproduction. Thus, the number of these advantage genotypes gradually increased. Unfortunately, recent changes in the consumption of a diet high in saturated fatty acid turned a relative advantage into a disadvantage.

There is a high probability that this type of selection based on the preference of a high proportion of phagocytic macrophages in adipose tissue (combined with high non-HDL cholesterol concentration) leads to human genome changes. It is almost impossible to find any direct support for this hypothesis, but there is one piece of indirect support from an interesting study of mortality changes in patients with familial hyperlipoproteinemia (FH) (Sijbrands et al. 2001). These data are based on a complete register of births and deaths of all Dutch individuals in the mid-19th century. The genealogical analysis of seven generations of three large families with point mutation V408M at exon 9 of the LDL receptor gene has identified 250 individuals with the same FH monogenic defect having only one founder couple. Familial hyperlipoproteinemia is a monogenic disease and the inheritance rate of this defective allele is $50 \%$. As a result, every other member of this large family will exhibit this defect with plasma cholesterol levels of around $10 \mathrm{mmol} / \mathrm{l}$ at this time. When comparing the standardized mortality of these six generations in the FH sample with the mortality in adequate generations of the whole Dutch population, bell-shaped curve was obtained (Fig. 2). In the middle of the 19th century the life expectancy of FH individuals was much longer than that of controls, the odd ratios being 0.7 in men and even 0.5 in women. Thereafter the mortality of FH individuals began to rise and the odd ratio of about 1.0 appeared at the beginning of the 20th century, when life expectancy in FH family and controls was equal. The highest point of this curve documented a shortest life of FH individuals and was located in the 60's of the last century. A slight decrease to the end of the 20th century was due to a higher knowledge of this disease, dietary changes and starting of statin therapy (Fig. 2).

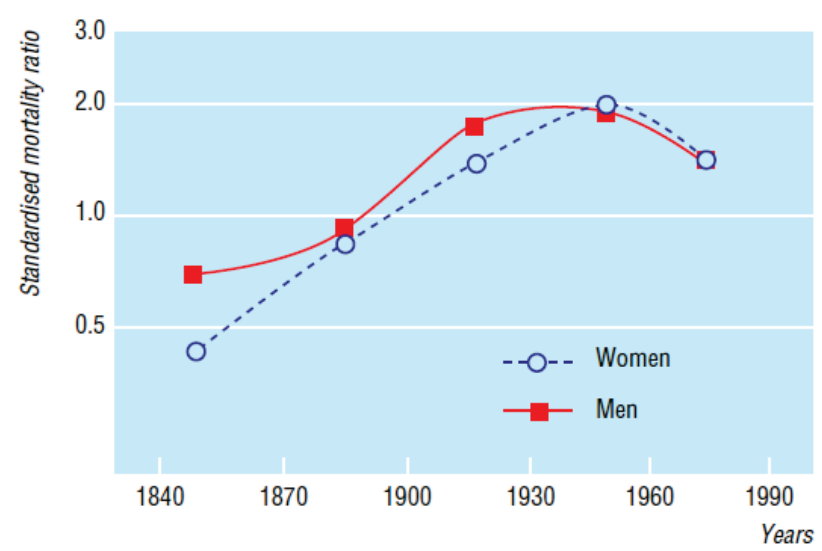

Fig. 2. Mortality from familial hypercholesterolemia according to sex and time (from Sijbrands et al. 2001 - with permission).

Consequently, hypercholesterolemia was an advantage in a period of high mortality from infectious diseases (due to a high proportion of phagocytic macrophages), whereas, in the period of high saturated fat diet (increasing cholesterol concentration) and high cardiovascular mortality, it became a very important disadvantage (with mortality in the FH family twice as high as in controls) (Sijbrands et al. 2001). These interesting data support our concept on the role of the genotype with highly phagocytic macrophages in adipose tissue. While this phenotype with high plasma cholesterol concentration decreased mortality from infectious disease two centuries ago, at present it stimulated atherogenesis and enhanced mortality from myocardial infarction and stroke.

Additional supportive data come from an epidemiological analysis of a cohort of 30,000 adults hospitalized for infection developing into in-hospital 
sepsis within $28 \mathrm{~h}$. The lowest quartile of the LDL cholesterol concentration was associated with significantly higher rates of sepsis, whereas the highest quartile is associated with lower rates of sepsis. No effect of HDL cholesterol concentration on the prevalence of sepsis was found (Guirgis et al. 2016). While the molecular mechanism of the relationship between sepsis and LDL cholesterol concentration has not been identified to date, the positive effect of higher cholesterol concentration was significant.

Similar evolutionary hypothesis has been proposed to explain frequent occurrence of hypertension, obesity and diabetes of African Americans. It is well known that American blacks have higher blood pressure, greater incidence of hypertension and more severe hypertensive complications compared to American whites (Gillum 1979, Rostand et al. 1982, Kissela et al. 2004, Egan et al. 2010). It is also evident that blood pressure of American blacks is more sensitive to salt intake than that of American whites (Luft et al. 1991, Weinberger 1996). Several studies reported higher blood pressure in Western hemisphere blacks compared to sub-Sahara African blacks (Waldron et al. 1982, Wilson et al. 1991). Although there are many studies comparing American blacks and whites, very few studies refer to the differences between American and African blacks. It is evident that American black hypertensives retain sodium load for a longer time than the white ones (Luft et al. 1979a,b) and they are also more sensitive to thiazide diuretics (Freis et al. 1988). This renal defect in sodium handling which is inherited to African Americans might be related to several allelic variants of genes involved in sodium handling and characterized as sodium conserving or heat adapted. They include angiotensinogen gene (Nakajima et al. 2004), G protein $\beta 3$ subunit (Young et al. 2005), $\beta_{2}$-adrenergic receptor gene (Young et al. 2005), epithelial $\mathrm{Na}^{+}$channel $\alpha$-subunit gene (Young et al. 2005), cytochrome P450 CYP3A5 gene (Thompson et al. 2004) and aldosterone synthase (CYP11B2) (White and Slutsker 1995). The individuals with enhanced genetic-based ability to conserve sodium had a clear advantage to survive sodium-depleting conditions. This might be a reason why present African Americans respond to sodium load in a different manner than do the whites (Wilson and Grim 1991). Indeed, American blacks with the highest quartile of African ancestry have $8 \%$ higher prevalence of hypertension compared to the lowest quartile (Marden et al. 2016). Recently, abnormal relationship of aldosterone production in subcutaneous adipocytes with obesity and hypertension was reported in African American subjects (Laffin et al. 2016). In the same time the activation of renin-angiotensin-aldosterone system was reported to be associated with insulin resistance and diabetes in African Americans studied in Jackson Heart Study (Joseph et al. 2016).

Wilson and Grim (1991) proposed that abnormal blood pressure of present African Americans might be not only due to a long-term adaptation of sub-Saharan populations to their low dietary salt intake and high sodium loss from sweating but also due to the process of „,natural selection" during the slavery era in the 16th to 19th century. The enhanced ability to conserve sodium was a distinct survival advantage during transatlantic slave trade voyages and New World slavery when the slave population often faced various infectious diseases associated with diarrhea, vomiting and fever which were common under the difficult living conditions of the slaves at that time. Diarrhea and vomiting, which caused enormous increase in sodium loss, enhanced further genetic selection.

It is still an open question whether hypertension or obesity can be considered as adaptive traits or not (Jackson 1991, Weder and Schork 1994, Speakman 2008). Hypertension is rarely found in societies with a hunter-gatherer style (Scotch 1963, Maddocks 1967, Prior et al. 1968, Oliver et al. 1975). Migration studies (Poulter et al. 1990, Agyemang et al. 2009a,b) support the important role of environment in hypertension development. However, the change in salt intake need not be the decisive causal factor because multiple risk factors increase during urbanization in Africa and/or migration of Africans to industrialized countries (Agyemang et al. 2009a). Recent RODAM studies performed in rural and urban Ghanaian residents as well as in Ghanaian migrants living in Amsterdam, London or Berlin address the changes in the incidence of hypertension and cardiovascular risk factors such as obesity, insulin resistance and diabetes Type 2 during the above mentioned transformation of the living environment. It should be noted that the incidence of hypertension, obesity, insulin resistance and diabetes Type 2 is lower in rural than in urban Ghanains, but the transition to great European cities substantially augmented these health problems (Agyemang et al. 2016, Agyemang et al. 2009b, Meeks et al. 2017, Agyemang et al. 2018). Surprisingly, neither abnormalities of lipid metabolism (Agyemang et al. 2009a) nor psychosocial stress (Agyei et al. 2014) seem to be responsible for this aggravation of 
cardiovascular or metabolic diseases.

In fact, the important role of so-called "thrifty genotype" was suggested not only in hypertension (Gleiberman 1973, Lev-Ran and Porta 2005, Gleiberman 2009) but also in diabetes and obesity (Neel 1962, Neel et al. 1998, Julius and Jamerson 1994) where an originally adaptive trait might become maladaptive when the living conditions have changed. Both disadvantage phenotypes with high LDL and increased blood pressure develop due to described natural selection and they become manifest especially when overnutrition exists in the majority of population in the recent world. Nevertheless, it remains to consider which part of the phenotypic changes induced by current urbanization and/or migration is dependent on the long-term adaptations to the original living conditions in sub-Saharan Africa.

In conclusion, both above mentioned scenarios on the possible evolution of cardiovascular risk phenotypes suggest that the advantages established on the basis of long-term natural can turn into the disadvantages if the living condition and/or nutrition were changed in the modern era. However, these evolutional scenarios might be modified by the environmental factors (such as climate or nutrition) and living conditions characteristic for distinct geographic areas.

\section{Conflict of Interest}

There is no conflict of interest.

\section{Acknowledgements}

This project was supported by the Ministry of Health, Czech Republic [00023001 - Institutional support and the grant NT14009/3] to Institute for Clinical and Experimental Medicine, Prague, Czech Republic (RP) as well as by grant $15-25396$ A of the Ministry of Health, Czech Republic to Institute of Physiology of the Czech Academy of Sciences, Prague, Czech Republic (JZ).

\section{References}

AGUILAR D, FERNANDEZ ML: Hypercholesterolemia induces adipose dysfunction in conditions of obesity and nonobesity. Adv Nutr 5: 494-502, 2014.

AGUILAR-RUIZ SR, TORRES-AGUILAR H, GONZALEZ-DOMINGUEZ E, NARVAEZ J, GONZALEZ-PEREZ G, VARGAS-AYALA G, MERAZ-RIOS MA, GARCIA-ZEPEDA EA, SANCHEZ-TORRES C: Human $\mathrm{CD} 16^{+}$and $\mathrm{CD} 16^{-}$monocyte subsets display unique effector properties in inflammatory conditions in vivo. J Leukoc Biol 90: 1119-1131, 2011.

AGYEI B, NICOLAOU M, BOATENG L, DIJKSHOORN H, VAN DEN BORN BJ, AGYEMANG C: Relationship between psychosocial stress and hypertension among Ghanaians in Amsterdam, the Netherlands - the GHAIA study. BMC Public Health 14: 692, 2014.

AGYEMANG C, ADDO J, BHOPAL R, AIKINS ADE G, STRONKS K: Cardiovascular disease, diabetes and established risk factors among populations of sub-Saharan African descent in Europe: a literature review. Global Health 5: 7, 2009a.

AGYEMANG C, OWUSU-DABO E, DE JONGE A, MARTINS D, OGEDEGBE G, STRONKS K: Overweight and obesity among Ghanaian residents in the Netherlands: how do they weigh against their urban and rural counterparts in Ghana? Public Health Nutr 12: 909-916, 2009b.

AGYEMANG C, MEEKS K, BEUNE E, OWUSU-DABO E, MOCKENHAUPT FP, ADDO J, DE GRAFT AIKINS A, BAHENDEKA S, DANQUAH I, SCHULZE MB, SPRANGER J, BURR T, AGYEI-BAFFOUR P, AMOAH SK, GALBETE C, HENNEMAN P, KLIPSTEIN-GROBUSCH K, NICOLAOU M, ADEYEMO A, VAN STRAALEN J, SMEETH L, STRONKS K: Obesity and type 2 diabetes in sub-Saharan Africans - is the burden in today's Africa similar to African migrants in Europe? The RODAM study. BMC Med 14: 166, 2016.

AGYEMANG C, NYAABA G, BEUNE E, MEEKS K, OWUSU-DABO E, ADDO J, AIKINS AD, MOCKENHAUPT FP, BAHENDEKA S, DANQUAH I, SCHULZE MB, GALBETE C, SPRANGER J, AGYEI-BAFFOUR P, HENNEMAN P, KLIPSTEIN-GROBUSCH K, ADEYEMO A, VAN STRAALEN J, COMMODOREMENSAH Y, APPIAH LT, SMEETH L, STRONKS K: Variations in hypertension awareness, treatment, and control among Ghanaian migrants living in Amsterdam, Berlin, London, and nonmigrant Ghanaians living in rural and urban Ghana - the RODAM study. J Hypertens 36: 169-177, 2018. 
BOBKOVÁ D, HONSOVÁ E, KOVÁŘ J, POLEDNE R: Effect of diets on lipoprotein concentrations in heterozygous apolipoprotein E-deficient mice. Physiol Res 53: 635-643, 2004.

EGAN BM, ZHAO Y, AXON RN: US trends in prevalence, awareness, treatment, and control of hypertension, 1988-2008. JAMA 303: 2043-2050, 2010.

FLATZ G, ROTTHAUWE HW: The human lactase polymorphism: physiology and genetics of lactose absorption and malabsorption. Prog Med Genet 2: 205-249, 1977.

FREIS ED, REDA DJ, MATERSON BJ: Volume (weight) loss and blood pressure response following thiazide diuretics. Hypertension 12: 244-250, 1988.

GILLUM RF: Pathophysiology of hypertension in blacks and whites. A review of the basis of racial blood pressure differences. Hypertension 1: 468-475, 1979.

GLEIBERMAN L: Blood pressure and dietary salt in human populations. Ecol Food Nutr 2: 143-156, 1973.

GLEIBERMAN L: Sodium, blood pressure, and ethnicity: what have we learned? Am J Hum Biol 21: 679-686, 2009.

GUIRGIS FW, DONNELLY JP, DODANI S, HOWARD G, SAFFORD MM, LEVITAN EB, WANG HE: Cholesterol levels and long-term rates of community-acquired sepsis. Crit Care 20: 408, 2016.

JACKSON FL: An evolutionary perspective on salt, hypertension, and human genetic variability. Hypertension 17 (Suppl I): I129-I132, 1991.

JOSEPH JJ, ECHOUFFO-TCHEUGUI JB, KALYANI RR, YEH HC, BERTONI AG, EFFOE VS, CASANOVA R, SIMS M, CORREA A, WU WC, WAND GS, GOLDEN SH: Aldosterone, renin, and diabetes mellitus in African Americans: the Jackson Heart Study. J Clin Endocrinol Metab 101: 1770-1778, 2016.

JULIUS S, JAMERSON K: Sympathetics, insulin resistance and coronary risk in hypertension: the 'chicken-and-egg' question. J Hypertens 12: 495-502, 1994.

KISSELA B, SCHNEIDER A, KLEINDORFER D, KHOURY J, MILLER R, ALWELL K, WOO D, SZAFLARSKI J, GEBEL J, MOOMAW C, PANCIOLI A, JAUCH E, SHUKLA R, BRODERICK J: Stroke in a biracial population: the excess burden of stroke among blacks. Stroke 35: 426-431, 2004.

KOVÁŘ J, POLEDNE R: The effect of moderate alcohol consumption on lipoprotein metabolism. Cor Vasa 46: $110-114,2004$.

KOVÁŘ J, TONAR Z, HECZKOVÁ M, POLEDNE R: Prague hereditary hypercholesterolemic (PHHC) rat - a model of polygenic hypercholesterolemia. Physiol Res 58 (Suppl 2): S95-S99, 2009.

KRÁlOVÁ LESNÁ I, POLEDNE R, FRONĚK J, KRÁLOVÁ A, SEKERKOVÁ A, THIEME F, PIŤHA J: Macrophage subsets in the adipose tissue could be modified by sex and the reproductive age of women. Atherosclerosis 241: 255-258, 2015.

KRÁlOVÁ LESNÁ I, KRALOVA A, CEJKOVA S, FRONEK J, PETRAS M, SEKERKOVA A, THIEME F, JANOUSEK L, POLEDNE R: Characterisation and comparison of adipose tissue macrophages from human subcutaneous, visceral and perivascular adipose tissue. J Transl Med 14: 208, 2016. Doi: 10.1186/s12967-0160962-1.

LAFFIN LJ, MAJEWSKI C, LIAO C, BAKRIS GL: Relationship between obesity, hypertension, and aldosterone production in postmenopausal African American women: a pilot study. J Clin Hypertens (Greenwich) 18: 1216-1221, 2016.

LEV-RAN A, PORTA M: Salt and hypertension: a phylogenetic perspective. Diabetes Metab Res Rev 21: 118-131, 2005.

LUFT FC, GRIM CE, FINEBERG N, WEINBERGER MC: Effects of volume expansion and contraction in normotensive whites, blacks, and subjects of different ages. Circulation 59: 643-650, 1979a.

LUFT FC, RANKIN LI, BLOCH R, WEYMAN AE, WILLIS LR, MURRAY RH, GRIM CE, WEINBERGER MH: Cardiovascular and humoral responses to extremes of sodium intake in normal black and white men. Circulation 60: 697-706, 1979b.

LUFT FC, MILLER JZ, GRIM CE, FINEBERG NS, CHRISTIAN JC, DAUGHERTY SA, WEINBERGER MH: Salt sensitivity and resistance of blood pressure. Age and race as factors in physiological responses. Hypertension 17 (Suppl I): I102-I108, 1991.

MADDOCKS I: Blood pressures in Melanesians. Med J Aust 1: 1123-1126, 1967.

MARDEN JR, WALTER S, KAUFMAN JS, GLYMOUR MM: African ancestry, social factors, and hypertension among non-Hispanic blacks in the Health and Retirement Study. Biodemography Soc Biol 62: 19-35, 2016. 
MATTAR R, DE CAMPOS MAZO DF, CARRILHO FJ: Lactose intolerance: diagnosis, genetic, and clinical factors. Clin Exp Gastroenterol 5: 113-121, 2012.

MEDBURY HJ, WILLIAMS H, LI S, FLETCHER JP: The bidirectional relationship between cholesterol and macrophage polarization. J Clin Cell Immunol 6: 1-7, 2015.

MEEKS KA, STRONKS K, ADEYEMO A, ADDO J, BAHENDEKA S, BEUNE E, OWUSU-DABO E, DANQUAH I, GALBETE C, HENNEMAN P, KLIPSTEIN-GROBUSCH K, MOCKENHAUPT FP, OSEI K, SCHULZE MB, SPRANGER J, SMEETH L, AGYEMANG C: Peripheral insulin resistance rather than beta cell dysfunction accounts for geographical differences in impaired fasting blood glucose among sub-Saharan African individuals: findings from the RODAM study. Diabetologia 60: 854-864, 2017.

MENDIZABAL I, VALENTE C, GUSMÃO A, ALVES C, GOMES V, GOIOS A, PARSON W, CALAFELL F, ALVAREZ L, AMORIM A, GUSMAO L, COMAS D, PRATA MJ: Reconstructing the Indian origin and dispersal of the European Roma: a maternal genetic perspective. PLoS One 6: e15988, 2011.

NAKAJIMA T, WOODING S, SAKAGAMI T, EMI M, TOKUNAGA K, TAMIYA G, ISHIGAMI T, UMEMURA S, MUNKHBAT B, JIN F, GUAN-JUN J, HAYASAKA I, ISHIDA T, SAITOU N, PAVELKA K, LALOUEL JM, JORDE LB, INOUE I: Natural selection and population history in the human angiotensinogen gene (AGT): 736 complete AGT sequences in chromosomes from around the world. Am J Hum Genet 74: 898-916, 2004.

NEEL JV: Diabetes mellitus: a "thrifty" genotype rendered detrimental by "progress"? Am J Hum Genet 14: 353-362, 1962.

NEEL JV, WEDER AB, JULIUS S: Type II diabetes, essential hypertension, and obesity as "syndromes of impaired genetic homeostasis": the "thrifty genotype" hypothesis enters the 21st century. Perspect Biol Med 42: 44-74, 1998.

NESSE RM, STEARNS SC, OMENN GS: Medicine needs evolution. Science 311: 1071, 2006.

OLDS LC, SIBLEY E: Lactase persistence DNA variant enhances lactase promoter activity in vitro: Functional role as a cis regulatory element. Hum Mol Genet 12: 2333-2340, 2003.

OLIVER WJ, COHEN EL, NEEL JV: Blood pressure, sodium intake, and sodium related hormones in the Yanomamo Indians, a "no-salt" culture. Circulation 52: 146-151, 1975.

POLEDNE R, KRALOVA LESNA I, KRALOVA A, FRONEK J, CEJKOVA S: The relationship between non-HDL cholesterol and macrophage phenotypes in human adipose tissue. J Lipid Res 57: 1899-1905, 2016.

POULTER NR, KHAW KT, HOPWOOD BE, MUGAMBI M, PEART WS, ROSE G, SEVER PS: The Kenyan Luo migration study: observations on the initiation of a rise in blood pressure. BMJ 300: 967-972, 1990.

PRIOR IA, EVANS JG, HARVEY HP, DAVIDSON F, LINDSEY M: Sodium intake and blood pressure in two Polynesian populations. N Engl J Med 279: 515-520, 1968.

ROGACEV KS, ZAWADA AM, EMRICH I, SEILER S, BÖHM M, FLISER D, WOOLLARD KJ, HEINE GH: Lower apoA-I and lower HDL-C levels are associated with higher intermediate $\mathrm{CD} 14^{++} \mathrm{CD} 16^{+}$monocyte counts that predict cardiovascular events in chronic kidney disease. Arterioscler Thromb Vasc Biol 34: 2120-2127, 2014.

ROSTAND SG, KIRK KA, RUTSKY EA, PATE BA: Racial differences in the incidence of treatment for end-stage renal disease. $N$ Engl J Med 306: 1276-1279, 1982.

SCOTCH NA: Sociocultural factors in the epidemiology of Zulu hypertension. Am J Public Health 53: 1205-1213, 1963.

SHEEDY FJ, GREBE A, RAYNER KJ, KALANTARI P, RAMKHELAWON B, CARPENTER SB, BECKER CE, EDIRIWEERA HN, MULLICK AE, GOLENBOCK DT, STUART LM, LATZ E, FITZGERALD KA, MOORE KJ: CD36 coordinates NLRP3 inflammasome activation by facilitating intracellular nucleation of soluble ligands into particulate ligands in sterile inflammation. Nat Immunol 14: 812-820, 2013.

SIJBRANDS EJG, WESTENDORP RGJ, DEFESCHE JC, DE MEIER PHEM, SMELT AHM, KASTELEIN JJP: Mortality over two centuries in large pedigree with familial hypercholesterolaemia: family tree mortality study. BMJ 322: 1019-1023, 2001.

SPEAKMAN JR: Thrifty genes for obesity, an attractive but flawed idea, and an alternative perspective: the 'drifty gene' hypothesis. Int J Obes (Lond) 32: 1611-1617, 2008. 
TAG CG, OBERKANINS C, KRIEGSHÄUSER G, INGRAM CJ, SWALlOW DM, GRESSNER AM, LEDOCHOWSKI M, WEISKIRCHEN R: Evaluation of a novel reverse-hybridization StripAssay for typing DNA variants useful in diagnosis of adult-type hypolactasia. Clin Chim Acta 392: 58-62, 2008.

TALL AR, YVAN-CHARVET L: Cholesterol, inflammation and innate immunity. Nat Rev Immunol 15: 104-116, 2015.

THOMPSON EE, KUTTAB-BOULOS H, WITONSKY D, YANG L, ROE BA, DI RIENZO A: CYP3A variation and the evolution of salt-sensitivity variants. Am J Hum Genet 75: 1059-1069, 2004.

VITTI JJ, GROSSMAN SR, SABETI PC: Detecting natural selection in genomic data. Annu Rev Genet 47: 97-120, 2013.

WALDRON I, NOWOTARSKI M, FREIMER M, HENRY JP, POST N, WITTEN C: Cross-cultural variation in blood pressure: a quantitative analysis of the relationships of blood pressure to cultural characteristics, salt consumption and body weight. Soc Sci Med 16: 419-430, 1982.

WEDER AB, SCHORK NJ: Adaptation, allometry, and hypertension. Hypertension 24: 145-156, 1994.

WEDER AB: Evolution and hypertension. Hypertension 49: 260-265, 2007.

WEINBERGER MH: Salt sensitivity of blood pressure in humans. Hypertension 27: 481-490, 1996.

WHITE PC, SLUTSKER L: Haplotype analysis of CYP11B2. Endocr Res 21: 437-442, 1995.

WILDE S, TIMPSON A, KIRSANOW K, KAISER E, KAYSER M, UNTERLÄNDER M, HOLLFELDER N, POTEKHINA ID, SCHIER W, THOMAS MG, BURGER J: Direct evidence for positive selection of skin, hair, and eye pigmentation in Europeans during the last 5,000 years. Proc Natl Acad Sci USA 111: 4382-4387, 2014.

WILSON TW, GRIM CE: Biohistory of slavery and blood pressure differences in blacks today. A hypothesis. Hypertension 17 (1 Suppl): I122-I128, 1991.

WILSON TW, HOLLIFIELD LR, GRIM CE: Systolic blood pressure levels in black populations in sub-Sahara Africa, the West Indies, and the United States: a meta-analysis. Hypertension 18 (3 Suppl): I87-I91, 1991.

YOUNG JH, CHANG YP, KIM JD, CHRETIEN JP, KLAG MJ, LEVINE MA, RUFF CB, WANG NY, CHAKRAVARTI A: Differential susceptibility to hypertension is due to selection during the out-of-Africa expansion. PLoS Genet 1: e82, 2005.

YVAN-CHARVET L, WELCH C, PAGLER TA, RANALLETTA M, LAMKANFI M, HAN S, ISHIBASHI M, LI R, WANG N, TALL AR: Increased inflammatory gene expression in ABC transporter-deficient macrophages: free cholesterol accumulation, increased signaling via toll-like receptors, and neutrophil infiltration of atherosclerotic lesions. Circulation 118: 1837-1847, 2008. 